\title{
METÓDY PRÍSTUPU PRI NAVRHOVANÍ NOVÝCH VEREJ NÝCH PRIESTOROV VO VIDIECKYCH SÍDLACH - PRÍPADOVÁ ŠTÚDIA BERNOLÁKOVO
}

\author{
METHODS OF APPROACH FOR DESIGNING NEW PUBLIC SPACES \\ IN RURAL SETTLEMENTS - CASE STUDY BERNOLÁKOVO
}

Ing. arch. Lucia Štefanc ová, Ph.D.

\begin{abstract}
ABSTRAKT
Článok sa zaoberá rôznymi metódami prístupu pri navrhovaní nových verejných priestorov vo vidieckych sídlach. Pomocou prípadovej štúdie Bernolákova - lokality „Nová lúka“ sú na 4 odlišných návrhoch prezentované idey vnímania verejných priestorov. Nové verejné priestory sú odlišné podl’a vplyvu, aký bude mat' nová zóna na celé Bernolákovo. Návrhy sú urbanisticky tzv. odstupňované od vytvárania monofunkčnej obytnej zóny, cez rekreačnú zónu Bernolákova, až po návrhy nového centra/subcentra obce. Záver je doplnený o štatistický prieskum zameraný na očakávania od novej zóny medzi súčasnými obyvatel’mi Bernolákova a Bratislavčanmi, ktorí by sa do novej zóny perspektívne prist'ahovali.
\end{abstract}

Kl'účové slová: vidiecke sídlo, verejný priestor, námestie, ulica, Bernolákovo, metódy navrhovania

\section{ABSTRACT}

The article deals with different methods of approach for designing new public spaces in rural settlements. A case study Bernolákovo - site "Nová lúka" presents four designs with different ideas of what public space means in rural settlement. New public spaces are different according to the future impact of the zone on a whole Bernolákovo. Urban studies are gradated from the creation of monofunctional residential zone, through recreation zone of Bernolákovo, til designing of the new center/sub-center of the settlement. The conclusion is completed by a statistical survey focused on the expectations of the new zone between existing residents of Bernolákovo and Bratislavians who would be the prospective newcomers in the zone.

Key words: rural settlement, public space, square, street, Bernolákovo, design methods

\section{VEREJNÉ PRIESTORY VIDIECKYCH SÍDIEL NA SLOVENSKU}

Vo verejných priestoroch vidieckeho sídla sa v minulosti aj dnes odohráva život jeho obyvatel'ov. Spravidla to bolo centrum obce vo forme námestia alebo ulice, na ktorých stáli kostol - hostinec obecný úrad. Postupom času sa k nim pridali d’alšie funkcie ako základná občianska vybavenost' (obchod, škola), kultúrny dom, požiarna zbrojnica a pod. „Súčasný stav vidieckych námestí, zdedenýz obdobia socializmu je taký, že mnohé postrádajú logické a aktívne funkčné využitie. Stali sa nezaujímavými, nevlúdnymi, upadajúcimi, zanedbanými „miestami nikoho“ s absenciou funkcií. Významné objekty občianskej vybavenosti, ktoré sú ich súčastou, sú často nefunkčné, stavebne chátrajú, prípadne sa nahrádzajú novostavbami.“(Sopirová, 2015, s.105)

V mnohých obciach prebieha demografický nárast obyvatel'stva a plánuje sa tvorba nových obytných zón na momentálne ,zelených lúkach“. Relatívne vel'ké územia pri súčasných trendoch navrhovania si 
žiadajú adekvátne vytváranie spoločenských verejných priestorov pre život komunity. „Smer skvalitňovania vnútornej štruktúry navodzujú najmä zákonitosti pretvárania a zákonitosti vztahové. $Z$ oblasti zákonitostí pretvárania ide najmä o zákonitosti valorizačného charakteru, ktoré navodzujú gradáciu, zhutňovanie, zväzovanie, zdokonalovanie alebo rozvoj.“ (Alexy, 1999, s.62) Pri návrhu novej obytnej zóny je treba metodicky postupovat' vzhl'adom na moderné trendy, potreby obce ale aj na názory obyvatel'ov, ktorí majú rôzne očakávania od novej štvrte.

\section{PRÍPADOVÁ ŠTÚDIA - BERNOLÁKOVO}

Bernolákovo je perspektívne vidiecke sídlo pri Bratislave, ktoré je oblúbeným bydliskom pre súčasných obyvatel’ov, ako aj pre Bratislavčanov, ktorí si realizujú sny o bývaní v rodinnom dome. Bernolákovo bolo vybrané ako prípadová štúdia na overenie 4 rôznych metód navrhovania nových verejných priestorov ako súčast' novej obytnej zóny.

\subsection{Súčasný stav Bernolákova}

Bernolákovo (historicky slov. Čeklís, Čeklýs aj Lužnica ; mad’. Cseklész; nem. Landschütz, chorv. Čekliš) je obec na Slovensku v okrese Senec. Obec je známa v medzinárodných kruhoch ako stredisko golfového športu. Nachádza sa tu golfové ihrisko, ktoré bolo na Slovensku vybudované ako prvé. V súčasnosti je Bernolákovo dynamicky sa rozvíjajúcou obcou s perspektívou do budúcnosti. Rozloha obce je 2843 ha a počet obyvatel'ov ku dňu 31.12.2015 je 6408 [6]. Počet obyvatel'ov s trvalým pobytom $\mathrm{v}$ Bernolákove neustále rastie vd’aka domovej výstavbe aj prirodzenému prírastku. Schválením Smerného územného plánu sa vytvorili podmienky pre výstavbu rodinných domov v nových oblastiach obce a súčasne bola vyčlenená oblast' pre podnikatel'ské aktivity, ktoré smerujú von zo zastavaného územia obce a sústred’ujú sa pri štátnej ceste Bratislava - Senec. Hlavné mesto vo vzdialenosti $20 \mathrm{~km}$ od Bernolákova ,spôsobuje efekt procesu expanzie na úkor podrobenia si krajiny a vytvára prostredie, ktoré v súčasnosti nie je ani mestom, ani vidiekom“ (Marcelli, 2009, s.201).
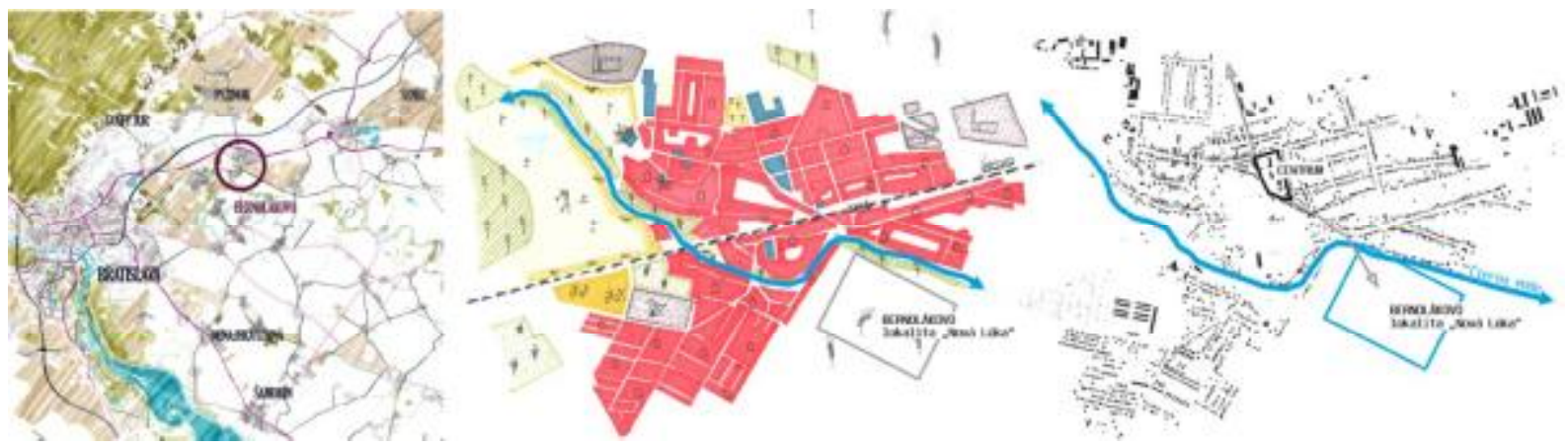

Obr. 1 Širšie vzt’ahy obce Bernolákovo (zl’ava poloha obce pri hlavnom meste, v strede funkčná analýza, vpravo špecifikácia lokalít „Nová lúka“ a centrum obce)

\subsection{Demografický predpoklad pre obec Bernolákovo}

Pri štatistickom zistovaní a sčítavaní obyvatel’ov Bernolákova v roku 2011 sa vytvoril predpoklad rapídneho nárastu počtu obyvatel'ov do roku 2013. V súčasnosti počet prihlásených obyvatel'ov k trvalému pobytu každým rokom rastie. Iba $7 \%$ obyvatel’ov je neprihlásených k trvalému pobytu. Z hladiska polohy obce v aglomerácii hlavného mesta sa predpokladá zväčšovanie, intenzifikácia sídla, nárast mestskosti a počtu obyvatel'ov. 
POCET OBYVATELOV OBCE BERNOLAKOVD

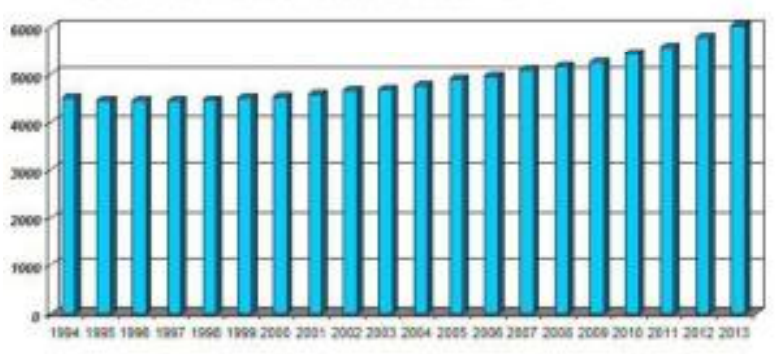

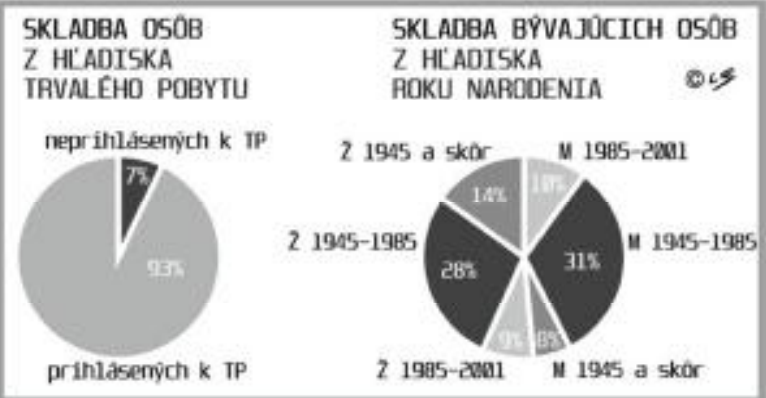

SKLADBA OSOB

Z HLADISKA

POKU NARDOENIA

Ls

2 1985-2001

Obr. 2 Demografický predpoklad nárastu obyvatel’ov s trvalý pobytom v obci Bernolákovo [6]

\subsection{Predpoklad urbanistického vývoja obce Bernolákovo}

Centrum Bernolákova tvorí obecný úrad, kultúrny dom, základná škola a základná občianska vybavenost'. Súčasné verejné priestory, ktoré dané funkcie prepájajú, sa sústred’ujú okolo centrálneho námestia s parkovými úpravami a posedením. $\mathrm{S}$ narastajúcim počtom obyvatel’ov a zväčšovaním intravilánu obce obytnou funkciou sa verejné priestory urbánneho charakteru námestia či ulice doplnenej občianskou vybavenost'ou a kultúrnym charakterom nezačali d’alej rozvíjat'. Dnešné centrum obce nezodpovedá súčasným požiadavkám na navrhovanie a využívanie spoločných priestorov. Územný rozvoj obce je navrhovaný južným smerom, kde v súčasnosti prebieha výstavba nových obytných zón. „Výsledky analýz preukázali priaznivejší stav sídelnej zelene v staršej zástavbe obce Bernolákovo oproti novovzniknutým obytným zónam, ktoré najviac obývajú mladé rodiny s det’mi a ktorých stav nie je priaznivý. Okrem vegetácie chýbajú detské ihriská, odpočivadlá, plochy pre stretávanie, rekreáciu a trávenie vol’ného času." (Gécová, 2015, s.108) Južne za riekou Čierna voda, sa nachádza lokalita „Nová lúka“ na tzv. „zelenej lúke“, ktorá je vhodným územím na aplikáciu rôznych metód, ako pristupovat' pri návrhu novej obytnej zóny s novými verejnými priestormi v duchu hodnôt spolupatričnosti, vzájomných kontaktov a identifikácie obyvatel’ov s miestom kde žijú.
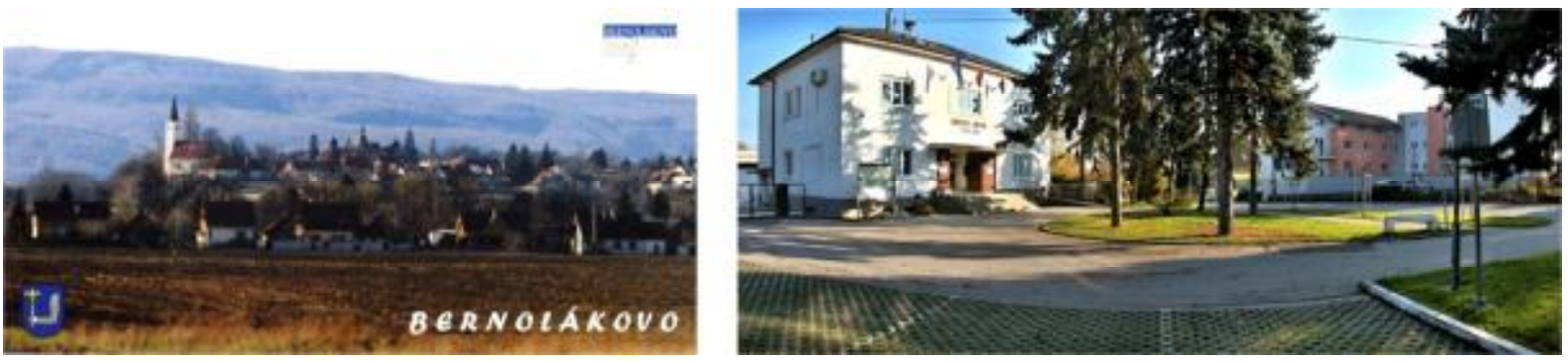

Obr. 3 Identita obce Bernolákovo (vl’avo panoráma, vpravo centrum mesta) [7]

\subsection{Lokalita „Nová lúka“}

Prípadová štúdia sa zameriava na nezastavanú lokalitu v Bernolákove s rozlohou 20 ha, ktorá je územným plánom navrhovaná ako štruktúra s prevahou bývania. Riešené územie „Nová lúka“ sa nachádza v juhovýchodnej časti obce Bernolákovo na území medzi brehom rieky Čierna voda a dopravným t’ahom smerom do obce Nová Dedinka. Na tomto území je zelená lúka s rozrastajúcou sa výstavbou rodinných domov bez občianskej vybavenosti, ktorá v súčasnosti málo vyhovuje potrebám obce. 


\section{METÓdY PRÍSTUPU PRI NAVRHOVANÍ NOVÝCH VEREJNÝCH PRIESTOROV}

Na lokalite „Nová lúka“ sa uskutočnil výskum v podobe 4 študentských urbanistických štúdií, ktoré sa zamerali na návrh novej obytnej zóny s jej novými verejnými priestormi. Každý návrh bol spracovaný inou metodikou v prístupe nazerania na to, čo znamená verejný priestor vo vidieckom sídle. Návrhy predstavujú spektrum 4 odlišných metód v navrhovaní verejných priestorov od monofunkčnej obytnej štvrte s minimálnymi verejnými priestormi, cez relaxačnú športovo-rekreačnú zónu Bernolákova až po novú urbanizovanú štvrt's nový centrom malého mesta.

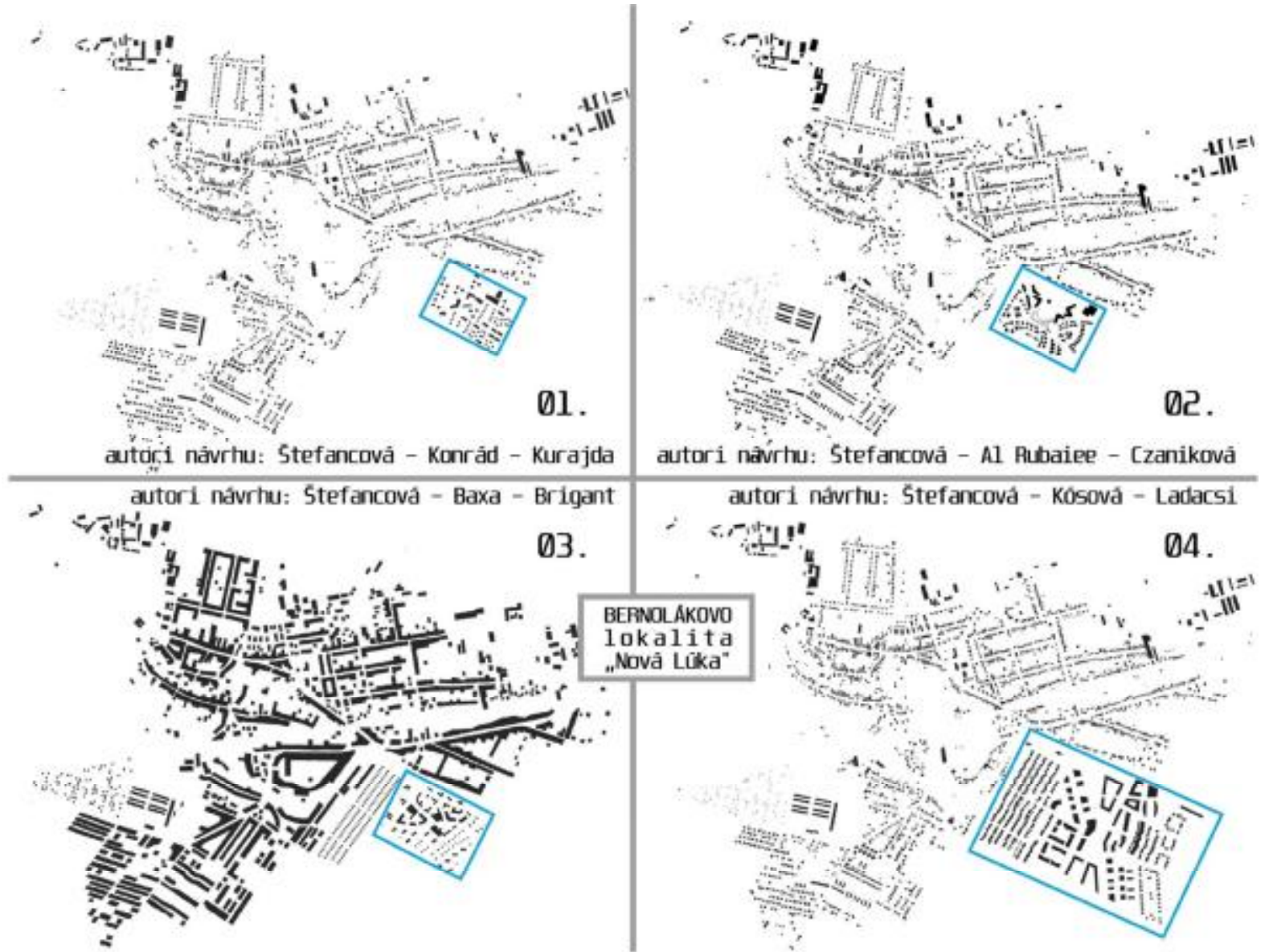

Obr. 4 Schwarzplany so 4 návrhmi lokality „Nová lúka“ (autori návrhov sú uvedení v obrázku)

\subsection{Metódy v navrhovaní pre novú obytnú štvrt's novými verejnými priestormi (VP)}

01. 5 \% VP je urbánneho charakteru, $30 \%$ VP je rekreačného charakteru, 65 \% VP sú ostatné /pokračovanie rozvoja vidieckeho sídla s prevažujúcou funkciou bývania s min. verejnými priestormi 02. 5 \% VP je urbánneho charakteru, $45 \%$ VP je rekreačného charakteru, $50 \%$ VP sú ostatné /vytvorenie rekreačnej zóny Bernolákova s parkovým charakterom doplnenej bývaním s verejnými priestormi športovo-relaxačného charakteru

03. $20 \%$ VP je urbánneho charakteru, $20 \%$ VP je rekreačného charakteru, $60 \%$ VP sú ostatné /vytvorenie nového subjadra paralelne fungujúceho so súčasným centrom, ktoré zabezpečuje potreby obyvatel'ov celého Bernolákova

04. $55 \%$ VP je urbánneho charakteru, $15 \%$ VP je rekreačného charakteru, $30 \%$ VP sú ostatné /vytvorenie nového centra Bernolákova $\mathrm{s}$ verejnými priestormi a funkciami zodpovedajúcimi štandardu malých miest 


\subsection{Popis návrhov novej obytnej štvrte Bernolákova s novými verejnými priestormi}

NÁVRH č. 01. Vytvorenie monofunkčnej obytnej zóny s prevahou bývania v typologicky rôznych formách zástavby. Novonavrhované verejné priestory v zóne sú lokalizované ako centrálne námestie $\mathrm{s}$ doplnkovou občianskou vybavenost’ou. Severná hranica pozdíž rieky Čierna voda je uvažovaná ako rekreačná lineárna prechádzková zóna.

Ideou návrhu je vytvorenie novej zóny s podobným charakterom ako je štruktúra Bernolákova (8\% zastavanost'), ktorá má spíňat' požiadavky nových obyvatel'ov a nemá ambíciu vyriešit' funkčné nedostatky celého mesta.

NÁVRH č. 02. Vytvorenie monofunkčnej obytnej zóny s prevahou bývania podl’a súčasných trendov, pričom nové verejné priestory v zóne sú navrhované ako rekreačná parková zóna s rozšíreným vodným kanálom z Čiernej vody. Doplnkovo je navrhnuté centrálne námestie s občianskou vybavenost'ou. Severná hranica pozdíž rieky Čierna voda je uvažovaná ako rekreačná lineárna prechádzková zóna.

Ideou návrhu je vytvorit’ novú rekreačnú zónu Bernolákova, ktorá je prirodzene lokalizovaná na nevyužívanej rieke.

NÁVRH č. 03. Vytvorenie polyfunkčnej zóny s bývaním, občianskou vybavenost’ou, administratívou i kultúrnymi zariadeniami. Navrhované verejné priestory námestia s aktívnym parterom dominujú v centre územia a plynulo sa napájajú smerom do jestvujúceho málo funkčného centra Bernolákova. Nekomerčná občianska vybavenost' (materská škola, základná škola, zdravotné stredisko) je lokalizovaná v severozápadnej časti územia. S týmito funkciami súvisia aj miesta pre športové aktivity na severe pri Čiernej vode. Pozdíž toku Čierna voda je lokalizovaný tzv. biokoridor - územie s väčšími plochami zelene doplnené len niekol'kými málopodlažnými bytovými domami. Pozdĺž Čiernej vody sa uvažuje s dominantnou rekreačnou zónou, ktorá sa lineárne napája do novej štruktúry vo forme „zelených pásov“, ktoré smerujú do budúceho rozvojového územia obce.

Ideou návrhu je vytvorenie druhého subcentra Bernolákova, ktoré má zabezpečit’ nároky všetkých obyvatel'ov.

NÁVRH č. 04. Vytvorenie nového centra Bernolákova za predpokladu presunutia funkcií ako mestský úrad a spoločenský dom z jeho súčasného malého centra. Návrh uvažuje s budúcim rozvojom obce južným a juhovýchodným smerom, preto sa centrum Bernolákova presúva do novej urbanizovanej polomestskej štruktúry.

$\mathrm{V}$ centre riešeného územia sa nachádza námestie s hlavnou pešou trasou a hlavným komunikačným uzlom. Centrum vytvárajú polyfunkčné bytové domy s pestrou občianskou vybavenost'ou: kultúrne stredisko, trh s tržnicou, škola, škôlka, malá športová hala a športové ihrisko, kaviarne, obchody. Projekt sa snaží o doplnenie doteraz chýbajúcej občianskej vybavenosti v obci a tým zlepšit kvalitu bývania. Pôvodné centrum Bernolákova je navrhované ako „srdce“ cyklistov. Návrh rieši spojenie dvoch cyklotrás, ktoré už v súčasnosti existujú resp. sú vo výstavbe. Navrhované spojenie cyklotrasy uvažuje s vybudovanými odpočinkovými stanicami pre cyklistov ako aj servisnými službami pre nich. Ďalšie „,srdcia“ - tematické zóny rozlíšené podl’a spoločenských aktivít sú navrhnuté aj pre: Šport verejné priestory obsahujú spevnené plochy na rôzne športové hry: skateboard, basketball, tenis, športové ihrisko; Mládež - verejné priestory zahŕňajú detské ihriská, verejné priestranstvá na stretávanie mladých mamičiek s malými det'mi a priestory pre aktívne využitie vol'ného času pre mládež a rôzne vol'nočasové aktivity pre tínedžerov; Kynologické stredisko - verejný priestor pre psíčkarov je navrhnutý pre chov a výcvik psov. Zástavba sa postupne rozvolnuuje smerom od centra $\mathrm{k}$ rodinným domom. Rodinné domy sú navrhnuté v štýle eco-house, t.j. niektoré rodinné domy majú spoločné nádrže na zber dažd’ových a odpadových vôd, ktoré sú recyklovatel'né. Nové typy bývania $\mathrm{v}$ štýle co-housing ponúkajú spoločné verejné priestory vo forme záhrad a priestorov na spoločenské aktivity, ktorými sa môžu zmenit' odizolované rodinné zvyklosti a zlepšit' susedské vzt'ahy.

Ideou návrhu je vnímanie rozrastajúceho sa vidieckeho sídla ako malého mestečka, ktoré potrebuje premiestnit' svoje nefunkčné centrum do novonavrhovanej zóny, ktorá bude novým centrom obce. Verejné priestory s funkciami zodpovedajú štandardu malých miest a mestská forma zástavby je v kontraste s existujúcou vidieckou zástavbou. 


\subsection{VYHODNOTENIE NÁVRHOV}

Výsledkami prípadovej štúdie sú 4 odlišné návrhy zóny „Nová lúka“ v Bernolákove.

Spoločnými črtami návrhov je vytvorenie novej obytnej štvrte s funkciou bývania v rôznych formách zástavby. Každý obyvatel' si v návrhoch nájde ideálny typ svojho bývania od rodinných domov, „ecohousing" domov, hybridného bývania, cez málopodlažné bytové domy až po bytové domy v parteri s občianskou vybavenost'ou. Ďalším spoločným motívom návrhov je využívanie rieky Čierna voda na rekreačné účely a tvorba lineárneho zeleného pásu popri vode.

Návrhy sú odlišné v myšlienke, akú funkciu bude mat' nová zóna a jej verejné priestory vzhl’adom na celé Bernolákovo. Návrhy sú urbanisticky tzv. odstupňované od vytvárania monofunkčnej obytnej zóny cez rekreačnú zónu Bernolákova až po návrhy nového centra/subcentra obce. Návrh 01 sa správa autonómne a zabezpečuje potreby nových obyvatel'ov zóny, naopak, návrh 02 vytvára rekreačnú zónu pre celú obec, návrh 03 je spojnicou 2 centier (starého a novonavrhovaného) a návrh 04 vytvára nové centrum obce. Navrhované verejné priestory sú rôzneho charakteru, ktorý vystihuje podstatu idey návrhu. V návrhoch 01,02 dominujú verejné priestory rekreačného, prírodného či parkového charakteru. V návrhoch 03, 04 dominujú verejné priestory urbánneho charakteru a simulujú námestia, ulice $\mathrm{v}$ parteri $\mathrm{s}$ občianskou vybavenost’ou či dominantné pešie priestranstvá. Vytvorenie monofunkčnej obytnej zóny s prevahou bývania v typologicky rôznych formách zástavby prevažuje $v$ návrhu 01 a 04.

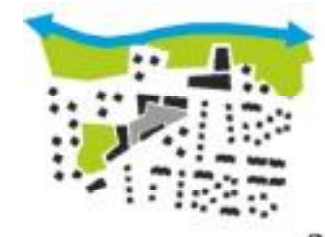

Ø1.

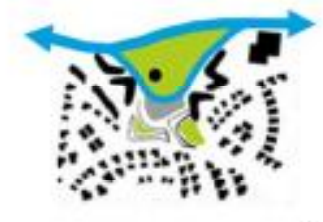

02.

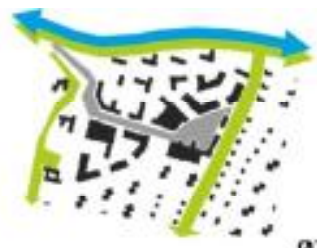

03.

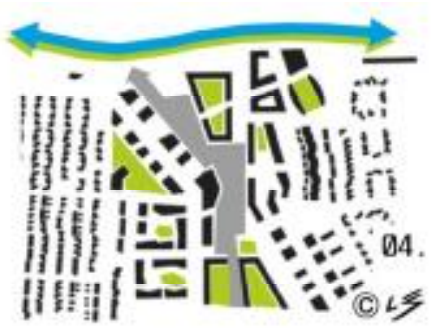

BERNOLÁKOV - lokalita "Novâ Lứka”

VEREJNYY PRIESTOR URBÁNNEHO CHARAKTERU [nảmestie, peŠie trasy doplnené ov a i.] VERE JNŶ PRIESTOR REKREAČ̃ÉHO CHARAKTERU (park, oddychovê zóny, vegetácia a 1.] Cierna voda

\section{Obr. 5 Vyhodnotenie návrhov $z$ hl’adiska typológie a charakteru verejných priestorov}

\section{4 ŠTATISTICKÝ PRIESKUM 2016}

Po návrhovej fáze prípadovej štúdie bol uskutočnený štatistický prieskum v čase január - marec 2016. Na otvorený anonymný prieskum odpovedalo 40 respondentov osobnou formou, formou sociálnych sietí a e-mailovým vyplnením. 40 respondentov bolo rozdelených na 20 súčasných obyvatelov Bernolákova a 20 obyvatel’ov Bratislavy, ktorí by sa do navrhovanej štvrte „Nová lúka“ mali fiktívne prist'ahovat'. Prieskum sa prostredníctvom 4 štúdií zameral na zistenie, čo pôvodní i noví obyvatelia od novej zóny očakávajú. Predpokladalo sa, že súčasné vidiecke obyvatel'stvo by privítalo mestskejšie prostredie verzus noví obyvatelia očakávajú vidiecky spôsob života.

Výsledkom štatistického prieskumu bolo zistenie, že Bratislavčania nepreferujú mestské prostredie, očakávajú obytnú zónu vidieckeho charakteru s minimom verejných priestorov. Opýtaní respondenti zdôvodnili, že na vidiek by sa st'ahovali kvôli bývaniu v rodinnom dome a pokojnému prostrediu. Bernolákovčania od novej štvrte očakávajú doplnenie funkcií, ktoré obci chýbajú a privítali by viac urbanizované verejné priestory. Sumárne sa ale všetci respondenti prikláňajú k myšlienke bývania $\mathrm{s}$ novou rekreačnou zónou na ostrove medzi Čiernou vodou a obtokovým kanálom (návrh 02). Rovnako sú obe skupiny zamerané proti vytvoreniu nového mestského centra Bernolákova (návrh 04). 


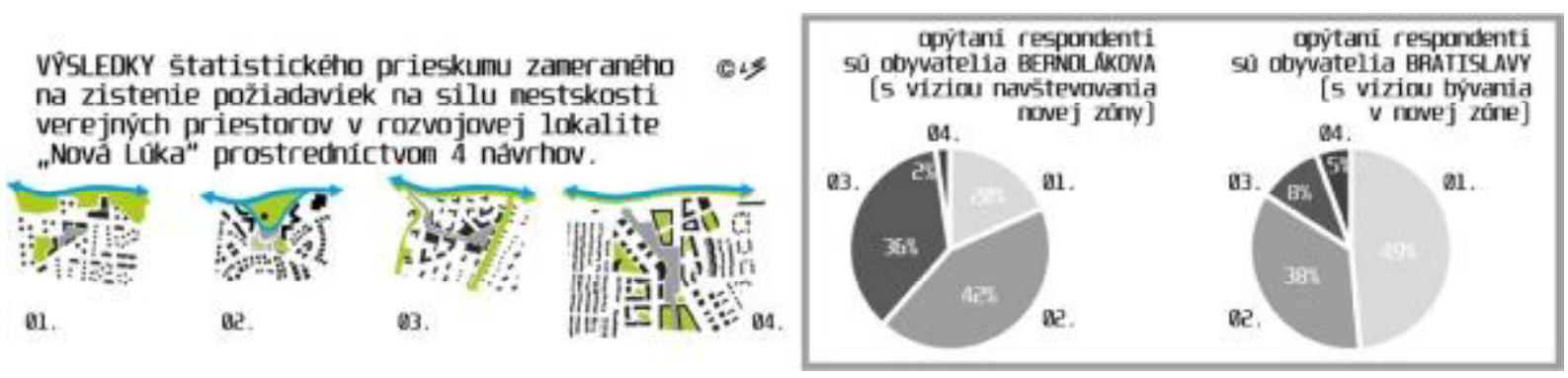

Obr. 5 Vyhodnotenie štatistického prieskumu zameraného na očakávania od novej zóny.

\section{ZÁVERY - AKO NAVRHOVAŤ VEREJNÉ PRIESTORY VIDIECKYCH SÍDIEL}

Za kvalitný a estetický verejný priestor (podl'a Bašovej - Štefancovej, 2016, s.68) sa považuje priestor so sociálnymi impulzami, rôznorodými funkciami, aktivitami, s l'udskou mierkou, trvalo udržatel'ný, zdravý, bezpečný a l'ahký na údržbu, priestor s regionálnou identitou a lokálnou znakovostou, priestor s prevahou pešieho pohybu a optimálnou organizáciou dopravy, priestor s jasne artikulovanými verejnými a súkromnými zónami, priestor s obnoveným stavebným fondom navrhnutý $\mathrm{v}$ duchu univerzálneho dizajnu, priestor zapamätatel'ný a l'ahký na orientáciu, priestor s koncepciou podl'a ročných období a s vyváženou druhovost’ou vegetačných prvkov a pod.

Príspevok prezentuje rôzne princípy a námety pri navrhovaní nových verejných priestorov. V prípade Bernolákova boli navrhované verejné priestory v novej štvrti aj urbánneho aj rekreačného charakteru $\mathrm{v}$ rôznej miere. Blízkost' hlavného mesta je devízou Bernolákova z funkčného i prevádzkového hl'adiska. Obyvatelia sa pri štatistickom prieskume priklonili k potrebe rekreačných a oddychových plôch, ktoré podporia charakter vidieckeho sídla. Podobne aj Bratislavčania, ktorí by sa eventuálne do novej zóny prestahovali, by uvítali prírodnejší charakter so základnou vybavenost’ou, pretože očakávajú pokojné bývanie na vidieku. Metodika ako navrhovat' nové verejné priestory vo vidieckych sídlach v nových (doteraz nezastavaných) zónach nie je jednoznačná. Je nutné analyzovat' polohu obce a blízkost' vel'kých miest, demografický a urbanistický vývoj, funkcie, ktoré obci chýbajú a pod. „Treba stanovit' jasné požiadavky, predstavy a stratégie samosprávy ako aj občanov, ktorí v obci žijú. “ (Sopirová, 2015, s.110)

\section{Použitá literatúra}

[1] ALEXY, Tibor. Vývoj a premena urbanistickej štruktúry. Vydavatel'stvo STU v Bratislave, Bratislava december 1999. Rozsah 103s. 1.vydanie, ISBN 80-227-1306-6.

[2] BAŠOVÁ, Silvia - ŠTEFANCOVÁ, Lucia. Creative parameters of urban spaces. In International Journal of Arts and Commerce. Vol. 5, No. 2 (2016), s. 54-68. ISSN 1929-7106.

[3] GÉCOVÁ, Katarína. Systém zelene v obci Bernolákovo. In Krajinná architektúra a krajinné plánovanie $v$ perspektíve. Zborník recenzovaných príspevkov vedeckej konferencie $s$ medzinárodnou účast’ou : Vedecká konferencia s medzinárodnou účastou a 19. kolokvium krajinárskych katedier. 1. -2. októbra 2015, Bratislava, Slovensko. 1. vyd. Bratislava : Nakladatel'stvo STU, 2015, s. 105-112. ISBN 978-80-227-4443-0.

[4] MARCELLI, Miroslav. Filozofi v meste. Vydavatel'stvo Kalligram, Bratislava 2009. Rozsah 256s. 2.vydanie, ISBN 978-80-8101-199-3.

[5] SOPIROVÁ, Alžbeta. Verejné priestory vidieckych sídiel - dopad intervencií na identitu. In Czech Journal of Civil Engineering [elektronický zdroj]. Vol. 1, iss. 2 (2015), s. 105-110. ISSN 2336-7148.

[6] http://www.bernolakovo.sk/infoobec/info-sk-obyvatelstvo.html

[7] http://www.bernolakovo.sk/zaujimav/zaujimav/pohlad/pohladnice.htm 